\title{
Influence of Nanolime and Curing Period on Unconfined Compressive Strength of Soil
}

\author{
Panbarasi Govindasamy, ${ }^{1}$ Mohd Raihan Taha, ${ }^{1,2}$ \\ Jamal Alsharef, ${ }^{1}$ and Kowstubaa Ramalingam ${ }^{1}$ \\ ${ }^{1}$ Department of Civil and Structural Engineering, Universiti Kebangsaan Malaysia (UKM), 43600 Bangi, Selangor, Malaysia \\ ${ }^{2}$ Institute for Environment and Development (LESTARI), Universiti Kebangsaan Malaysia (UKM), 43600 Bangi, Selangor, Malaysia
}

Correspondence should be addressed to Panbarasi Govindasamy; gpam_21@yahoo.com

Received 20 October 2016; Revised 21 February 2017; Accepted 6 March 2017; Published 3 April 2017

Academic Editor: Teodoro M. Miano

Copyright (C) 2017 Panbarasi Govindasamy et al. This is an open access article distributed under the Creative Commons Attribution License, which permits unrestricted use, distribution, and reproduction in any medium, provided the original work is properly cited.

This paper presents the improvement of the unconfined compressive strength (UCS) of soil by mixing different percentages of nanolime and 5\% lime with soil. The UCS of treated soil increased significantly over curing time with increasing percentage of nanolime. The optimum results were reached at only $0.5 \%$ nanolime admixtures which were much higher than $5 \%$ lime admixture. This may be due to higher ability of nanolime to flocculate and agglomerate the soil particles compared with the lime. In addition, the lime could fill only the micropores while nanolime could fill the micro- and nanopores as well. The strength gain is inversely proportional to the remolded moisture content and curing period. However, when the content of nanolime used is larger than $0.5 \%$, nanolime particles are not uniformly dispersed. Therefore, a weak area in the form of voids is created, consequently the homogeneous hydrated microstructure cannot be formed, and finally the strength will decrease.

\section{Introduction}

In geotechnical engineering practice, soft clay is common and widely encountered. It forms a great challenge to geotechnical engineers, particularly in metropolitan areas due to its low strength and high compressibility. This type of ground at a construction site is not always suitable for supporting structures such as buildings, bridges, highways, and dams. In order to overcome this problem several methods have been employed worldwide to improve engineering characteristics of soils such as ground improvement techniques. These techniques are used to prepare soft soils for construction and they have become much more common nowadays.

In the 1970s and 1980s, soil stabilization by admixture was developed in Japan. Soil treated in such a manner was better than the original soil in terms of strength, reduced compressibility, and hydraulic conductivity [1]. The use of lime as admixture to improve soft ground has also long been used such as in ancient China and Egypt [2].

Lime has been found to be an effective stabilizer, which significantly changes the characteristics of a soil to produce long-term permanent strength and stability, particularly with respect to the action of water and frost [3]. However, previous work in stabilization of clayey soils with lime has shown that small amounts of lime considerably improve workability but contribute little to strength, whereas larger amounts of lime only improve the strength and bearing capacities of soil. In the results of unconfined compressive strength, kaolinitic and montmorillonitic clayey soils were found to be well stabilized with larger amount of lime, alone, whereas illitic-chloritic clayey soils require addition of fly ash to obtain significant gains in the strength [4].

\section{Nanotechnology in Geotechnical Engineering}

Nanotechnology is a rapidly emerging technology with vast potential to create new materials with unique properties and to produce new and improved products for numerous applications. At scales of nanometer range, materials can exhibit unique properties different from their bulk state. Nanotechnological achievements provided a modern approach in geotechnical engineering also. Nanotechnology can be 
applied in geotechnical engineering by studying the soil structure in nanometer scale to gain a better understanding of soil nature [5].

In recent years, application of nanomaterials in engineering studies has drawn interest by researchers from all over the world. Nanoparticles are referred to as nanocrystals due to its crystalline form. The transition from microparticles to nanoparticles can be attributed to positive changes in physical properties. This is because of the increase in ratio of surface area and changes in volume. Due to the large surface area of nanoparticles, a lot of interactions occur between intermixed materials such as nanocomposites which leads to an increase in strength of the materials [6].

Taha [7] has presented the laboratory experiments to study the fundamental geotechnical properties of mixtures of natural soils and its product after ball milling operation. The product after ball milling process was termed nanosoil herein. The plastic and liquid limits of soil mixtures consisting of $98 \%$ original soil and $2 \%$ nanosoil increased compared to the values of $100 \%$ original soil. Since the increase in the liquid limit was less than that of plastic limit, it reduced the plasticity index which is advantageous in many geotechnical constructions. These results showed that a small amount of these milled particles or nanosoil can provide significant improvement in the geotechnical properties of soil.

The materials in nanodimensions have specific chemical and physical properties, linked to the physical and chemistry properties of very small particles with respect to the massive materials. Comparably, nanosize is more reactive than its original size and act as a good catalyst. Materials with new applications could be produced due to the increase in total size of surface area. Thus, these materials become more reactive and suitable for improving the properties of clayey soil for various applications [7]. Increasing research and development is ongoing using nanoparticles as filler or additives for various desired effects [8].

Interesting applications for nanomaterials are being found within the conservation of cultural heritage. Nanolime is a recent type of nanoproducts. Nanolime is aimed at overcoming some of the limitations of traditional lime-based materials, such as the difficulty in achieving a complete carbonation, while maintaining their advantages [9]. This paper presents the improvement of UCS of original soil by mixing different percentages of nanolime and 5\% lime with soil. Finally, it gives information about optimum nanolime content for the studied soil to improve the unconfined compressive strength at four different curing periods.

\section{Materials}

3.1. Properties of Original Soil. The basic geotechnical properties and classification of the soil collected from the hilly area of Universiti Kebangsaan Malaysia (UKM) were listed in Table 1. Original soil was collected at shallow depth after removing the top $0.5 \mathrm{~m}$ depth of ground surface. The natural water content was $22.8 \%$ while the maximum dry density $\left(\gamma_{\mathrm{dmax}}\right)$ and optimum water content $\left(\omega_{\text {opt }}\right)$ were $1.87 \mathrm{~g} / \mathrm{cm}^{3}$ and $15.6 \%$, respectively. According to the unified soil classification system (USCS), the tested soil was classified under
TABLE 1: Basic properties of original soil.

\begin{tabular}{lc}
\hline Property & Value \\
\hline Natural water content, $\left(\omega_{n}\right)(\%)$ & 22.8 \\
Maximum dry density, $\gamma_{\text {dmax }}\left(\mathrm{g} / \mathrm{cm}^{3}\right)$ & 1.87 \\
Optimum water content, $\left(\omega_{\text {opt }}\right)(\%)$ & 15.6 \\
Liquid limit $(\mathrm{LL})(\%)$ & 31 \\
Plastic limit $(\mathrm{PL})(\%)$ & 18.7 \\
Plasticity index PI $(\%)$ & 12.3 \\
USCS classification & $\mathrm{CL}$ \\
Specific gravity $\left(\rho_{s}\right)$ & 2.63 \\
$\%$ gravel & 0.0 \\
$\%$ sand & 57.5 \\
$\%$ silt & 22.5 \\
$\%$ clay & 20.0 \\
\hline
\end{tabular}

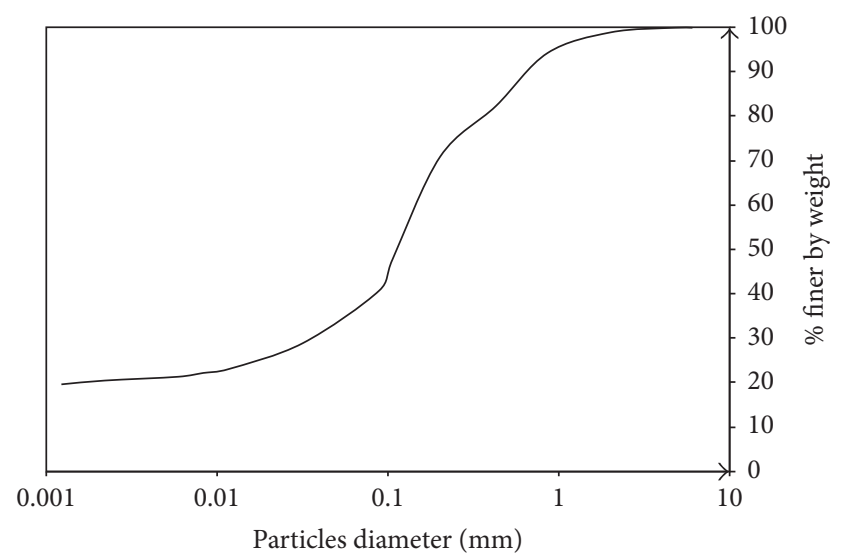

FIgURE 1: Particles sizes distribution curve of original soil.

group symbol of CL. The soil contained no gravel. Meanwhile, the fractions of sand, silt, and clay are 57.5, 22.5, and $20 \%$, respectively. Figure 1 presents the distribution of particle size of original soil.

3.2. Chemical Characterization of Soil and Additives. Lime and nanolime were the two additives used for this of soil improvement. Lime powder was obtained from local market. Nanolime powder was imported from Strem Chemicals, Inc., Mulliken Way, Newburyport, Massachusetts, United States. The results of X-ray fluorescence (XRF) test for lime used as additive are illustrated in Table 2 for both regular grades and nanogrades. It can be seen that the nanolime has greater purity than the lime. A large trace of $\mathrm{CaO}$ was available in both grades, while lime contained a noticeable amount of $\mathrm{MgO}(1.75 \%)$ compared to $1.24 \%$ which was available in nanolime. Table 3 presents the chemical composition of original soil, where the silica and alumina are the main components and then iron oxide comes as a third most abundant component.

$\mathrm{X}$-ray diffraction (XRD) test was used to analyze the crystallite size of the particles. The results of this test in the form of relation graphs between intensity and 2 theta 
TABLE 2: Chemical composition of lime additive.

\begin{tabular}{lcccccccccccc}
\hline & $\mathrm{CaO}$ & $\mathrm{MgO}$ & $\mathrm{SO}_{3}$ & $\mathrm{SiO}_{2}$ & $\mathrm{Al}_{2} \mathrm{O}_{3}$ & $\mathrm{Fe}_{2} \mathrm{O}_{3}$ & $\mathrm{SrO}$ & $\mathrm{Cl}$ & $\mathrm{K}_{2} \mathrm{O}$ & $\mathrm{ZnO}$ & $\mathrm{ZrO}_{2}$ \\
\hline Lime & $95.21 \%$ & $1.75 \%$ & $0.56 \%$ & $0.22 \%$ & $0.13 \%$ & $0.08 \%$ & $0.03 \%$ & $0.02 \%$ & $0.01 \%$ & - & - \\
Nanolime & $97.22 \%$ & $1.24 \%$ & $0.02 \%$ & $0.47 \%$ & $0.09 \%$ & $0.07 \%$ & $0.03 \%$ & $0.01 \%$ & $0.01 \%$ & $48 \mathrm{ppm}$ & $12 \mathrm{ppm}$ \\
\hline
\end{tabular}

TABLE 3: Chemical composition of original soil.

\begin{tabular}{lccccccccc}
\hline $\mathrm{SiO}_{2}$ & $\mathrm{Al}_{2} \mathrm{O}_{3}$ & $\mathrm{Fe}_{2} \mathrm{O}_{3}$ & $\mathrm{TiO}_{2}$ & $\mathrm{~K}_{2} \mathrm{O}$ & $\mathrm{MgO}$ & $\mathrm{ZrO}_{2}$ & $\mathrm{SO}_{3}$ & $\mathrm{CaO}$ & $\mathrm{O}$ \\
\hline $60.35 \%$ & $21.83 \%$ & $4.36 \%$ & $1.13 \%$ & $0.51 \%$ & $0.47 \%$ & $0.09 \%$ & $0.08 \%$ & $0.05 \%$ & $0.08 \%$ \\
\hline
\end{tabular}

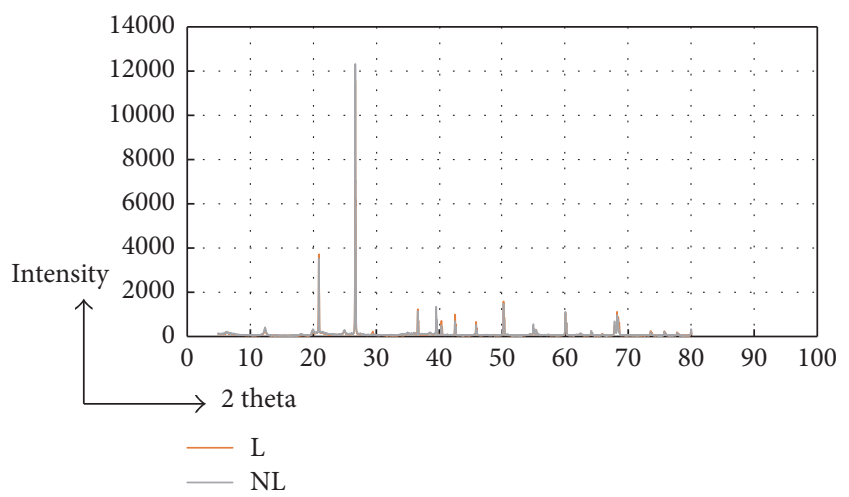

FIGURE 2: Relation graph between intensity and 2 theta for lime and nanolime material.

are shown in Figure 2. The values for the full width at half maximum (FWHM) and the theta were obtained. These numbers were analyzed using Scherer's formula to measure the crystallite size of lime and nanolime.

\section{Methodology}

4.1. Preparation of Test Samples. Samples prepared for UCS tests are original soil, soil mixed with lime, and soil mixed with nanolime. The percentages of nanolime mixed with soil were $0.2 \%, 0.3 \%, 0.5 \%, 0.8 \%$, and $1 \%$ each. $5 \%$ lime was added to soil. This amount was the value of Initial Lime Consumption (ILC) for the studied soil which was determined based on the $\mathrm{pH}$ test. The dry original soil was mixed with lime or nanolime percentages and then the water was added to the mixture. Contents of $12,14,16$, and $18 \%$ of water from the dry weight of soil were added for every series of the mixture. In this method, mixing is carried out into two stages. Initially, the mixing was done through hand-mixing where the quantity of soil was divided into ten layers and each layer was sprayed with the required amount of additives. Each layer was mixed alone and then put in the pot and then the mixture is mixed again by horizontal cylindrical mixer for at least 3 hours [11]. The dry mixtures in the pot were sprayed with the required amount of water during the mixing process. The type of water used for preparing samples was distilled water. This procedure was found to be the best method to obtain homogeneous samples since homogeneous color was obtained after compaction.
4.2. UCS Test. The UCS test was used to determine the strength of original soil and evaluate the strength evolution of soil-lime and soil-nanolime mixtures. Strain-controlled machine was used to perform this test and BS 1377-7:1990 was employed. In this test, $5 \%$ lime for soil-lime and different content of nanolime were used for soil-nanolime mixtures, that is, $0.2,0.3,0.5,0.8$, and $1.0 \%$ by weight of dry soil. The specimens were prepared with remolded water contents of 12 , 14,16 , and $18 \%$. The Proctor test was conducted directly after mixing process.

A cylindrical mould of diameter of $38 \mathrm{~mm}$ was inserted in the compacted soil. Thereafter, the specimen was ejected from this mould using a hydraulic extruder. The length of the specimen was trimmed to twice the diameter. A tolerance of $8 \%$ less and $12 \%$ more than the standard length is allowed according to BS standard. Plastic wrap was used to keep the cylindrical specimens of unconfined compression test for curing periods of $0,7,28$, and 56 days.

4.3. X-Ray Fluorescence (XRF) Analysis. XRF is a nondestructive method for the elemental analysis of solids and liquids. In this technique, the samples were irradiated by an intense $\mathrm{X}$-ray beam causing the emission of fluorescent $\mathrm{X}$-rays. The X-rays emitted were detected by energy dispersive or wavelength dispersive detector. The energies or wavelengths were used to identify the elements present in the samples, whereas concentrations (quantities) were determined by the intensity of the X-rays. XRF analysis was conducted for the native materials, that is, UKM soil, lime, and nanolime, to obtain their chemical compositions and to create a perception about the expected reactants using Bruker S4 Pioneer model. The soil was milled and sieved at $425 \mu \mathrm{m}$ before XRF analyses were done.

4.4. X-Ray Diffraction (XRD) Analysis. XRD analysis was conducted using Bruker AXS, Karlsruhe, Germany, model D8 Advanced. The source of $\mathrm{X}$-ray was $\mathrm{Cu}-\mathrm{K} \alpha$ with input voltage of $40 \mathrm{kV}$ and current of $40 \mathrm{~mA}$. The wave length and step size were $0.15406 \mathrm{~nm}$ and $0.025^{\circ} / 0.1 \mathrm{~s}$, respectively.

$\mathrm{XRD}$ is a very reliable and dominant technique for minerals identification in soils and rocks [12]. This analysis was conducted to identify the chemical reactions and development of new products if any. When X-rays interact with a crystalline substance, a definite diffraction pattern is achieved. Every crystalline substance has a specific pattern and the same substance always produces the same pattern and in a mixture 


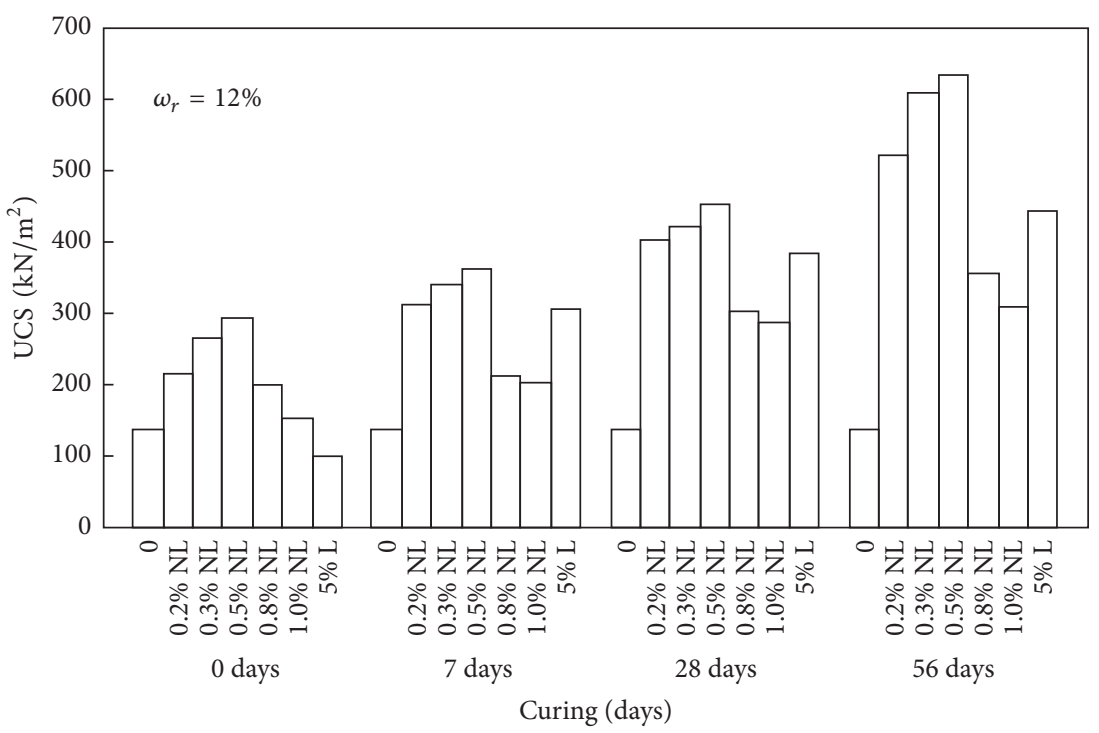

FIGURE 3: UCS development over curing periods for original soil, soil-nanolime mixtures, and soil-lime mixture at remolded water content of $12 \%$.

of substances every substance gives its independent pattern from the others [13]. In this study, XRD analysis was used to determine the crystallite size of lime and nanolime particles using Scherer's formula.

4.5. Field-Emission Scanning Electron Microscope (FESEM). Supra 55VP Zeiss 2008 at CRIM, UKM, for FESEM test was employed to analyze the untreated and the treated soil samples to observe the change in the soil aggregation and formation of any new material. Initially the same percentages of lime and nanolime were hand mixed with water content according to their respective optimum moisture content level. The soil-lime and nanolime mixtures were kept in polyethylene bags and cured at room temperature for 28 days. Then the mixtures were oven dried for 24 hours at temperature of $100 \pm 1^{\circ} \mathrm{C}$ before they were milled and sieved at $425 \mu \mathrm{m}$. FESEM in this study was conducted to disclose the morphology of the native materials and to observe the morphology of the materials after mixing and curing. The change in the soil aggregation and formation of new material can be observed through this analysis. Since the microscope of FESEM uses electron in place of light, the objects that need to be observed by FESEM must be able to be conductive for current. Therefore, all the specimens in this study were coated by a very thin layer of gold. Besides that, mean particle sizes of lime and nanolime were also determined by analyzing the images provided by FESEM analysis.

\section{Results and Discussions}

5.1. Impact on UCS. Figures 3-6 show the strength gain over curing period for various contents of nanolime and $5 \%$ lime, respectively. The results of UCS test for the pure soil showed that there was a high sensitivity towards the remolded water contents $\left(\omega_{r}\right)$. Although the UCS for $\omega_{r}$ of $\omega_{\text {opt }}(16 \%)$ was $183.67 \mathrm{kN} / \mathrm{m}^{2}$, the strength value started off at $138 \mathrm{kN} / \mathrm{m}^{2}$ and increased to $157 \mathrm{kN} / \mathrm{m}^{2}$ before dropping to $74 \mathrm{kN} / \mathrm{m}^{2}$ at $\omega_{r}$ at 12,14 , and $18 \%$, respectively. A dramatic increase occurred with the initial water content till optimum content of water. However, UCS value decreased drastically at $18 \%$ of water content. The reduction in soil strength as water content increase may be related to the effect of soil suction. The soil suction formed meniscus between neighboring particles which creates bonding attractive normal force between them. This is likely to be the case at optimum condition. As extra water is available (the condition of moisture content beyond optimum level), the attractive force by the soil suction induced water to form between soil particles leading to reduction of friction between them.

Moreover, a dramatic increase in soil strength with curing time was realized after mixing the tested soil with nanolime and lime. This strength gain was directly proportional to the curing periods. The results demonstrate that increasing the amount of additive increases the UCS. It can be seen more apparent with the mixture of nanolime. The UCS for mixtures of $\omega_{r}$ of $16 \%$ after 1 -day curing periods were 184,393 , $405,485,325$, and $241 \mathrm{kN} / \mathrm{m}^{2}$ for original soil, soil-nanolime mixtures of $0.2,0.3,0.5,0.8$, and $1.0 \%$, and soil-lime dose at $5 \%$, respectively. These values of UCS grew, respectively, to $184,615,660,685,491,289$, and $559 \mathrm{kN} / \mathrm{m}^{2}$ for curing period of 56 days.

In the same context, nanolime induced noticeable increase in UCS of soil-nanolime mixtures; that is, the strength of the mixtures with nanolime was higher than the strength of mixtures with lime. These may be due to higher ability of nanolime to flocculate and agglomerate the soil particles compared with the lime. Agglomeration and flocculation occured with the availability of $\mathrm{Ca}^{+2}$ cations. Ions exchange mechanism possibly took place between monovalent ions $\left(\mathrm{Ca}^{+2}\right)$ with divalent $\left(\mathrm{Na}^{+}, \mathrm{H}^{+}\right)$ions leading to reduction of repulsion forces and bridging the clayey particles of negative surface ions. This may again be related to the reactivity of 


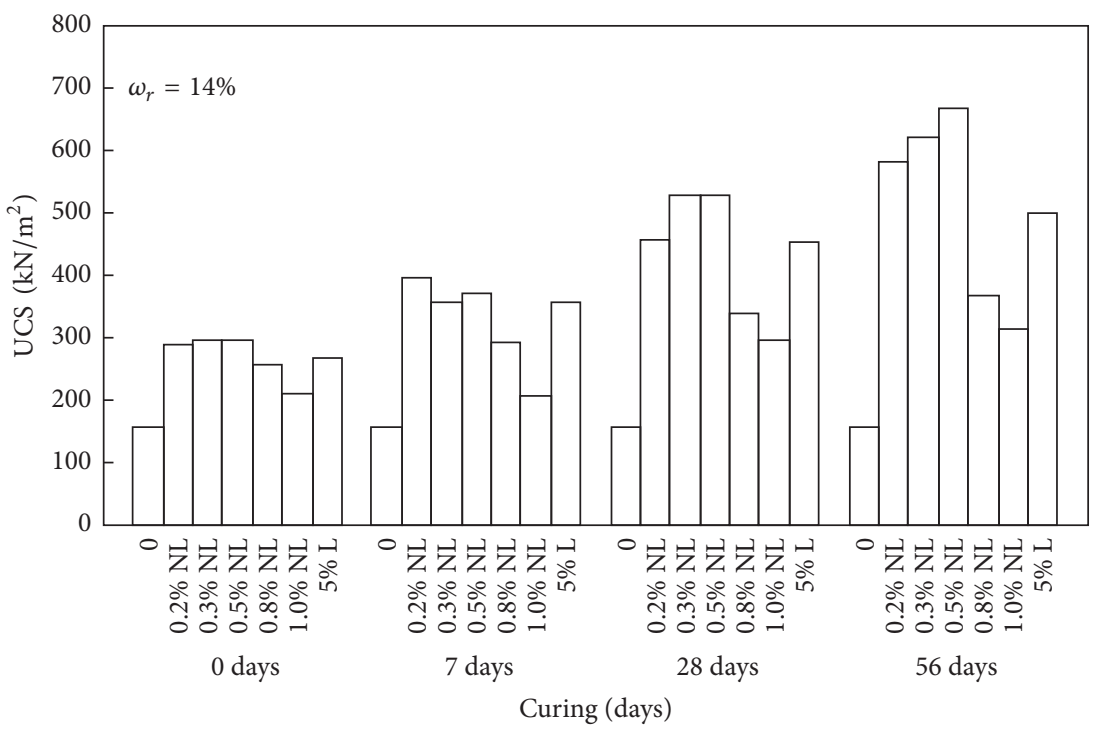

FIGURE 4: UCS development over curing periods for original soil, soil-nanolime mixtures, and soil-lime mixture at remolded water content of $14 \%$.

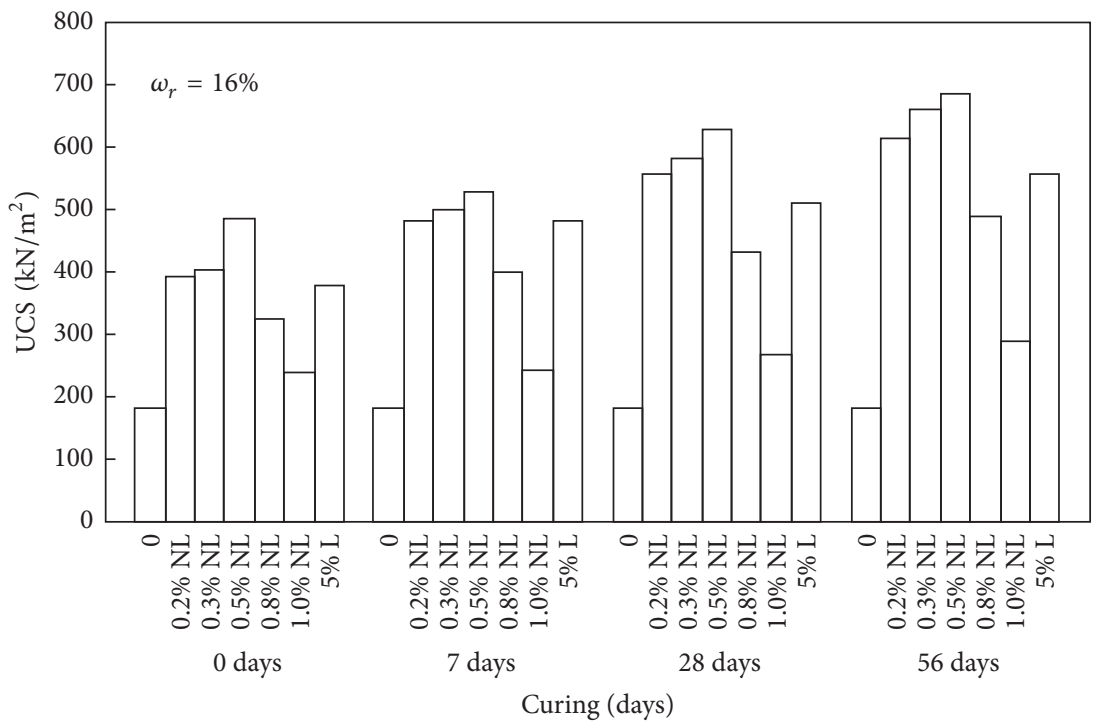

FIGURE 5: UCS development over curing periods for original soil, soil-nanolime mixtures, and soil-lime mixture at remolded water content of $16 \%$.

nanolime and its ability to release more $\mathrm{Ca}^{+2}$ ions than lime. This is supported with the purity of nanolime which is higher than the lime as shown in Table 2.

Compared with natural soil, Table 4 presents the percentage of improvement in the UCS of soil-lime mixtures after 56-day curing periods. The improvement was more than $320 \%$ for lime mixtures and about $459 \%$ for nanolime mixtures depending on the remolded water contents and lime or nanolime contents. This is in comparison with 0,7 , and 14 days of curing period to 56 days of curing period which enhances the strength of the treated soil.

Although the UCS for all the soil-nanolime mixtures reportedly increased with nanolime percentages compared to the natural soil, the value slightly decreases among the nanolime percentages. It was found to decrease with the increase of nanolime from $0.8 \%$ to $1.0 \%$. When the content of nanoparticles used is large, nanoparticles are not uniformly dispersed. Therefore, a weak area in the form of voids is created. Consequently, the homogeneous hydrated microstructure cannot be formed and finally the strength will decrease.

Arabani et al. [14] have studied the UCS test of soil cement mixed with different percentages of nanoclay at 7, 14, and 28 days of curing period. The compressive strength of soil cement mixture with $1 \%$ ratio of nanoclay was $67 \%$ higher than control mixture. The 14 days' and 28 days' compressive strength of nanoclay with soil cement mixture were found to decrease with the increase in nanoparticles ratio from 3 


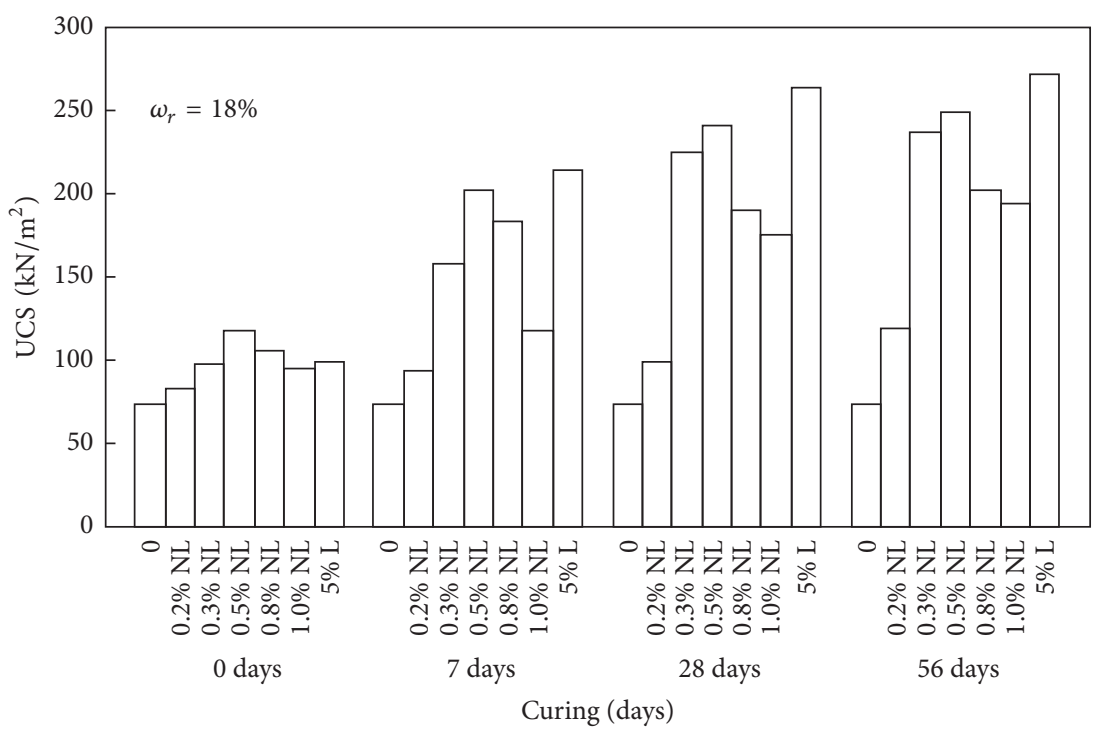

FIGURE 6: UCS development over curing periods for original soil, soil-nanolime mixtures, and soil-lime mixture at remolded water content of $18 \%$.

TABLE 4: Improvement of UCS for soil-nanolime mixtures after 56 days' curing period.

\begin{tabular}{|c|c|c|c|c|c|c|}
\hline \multirow[b]{3}{*}{$\begin{array}{l}\text { Nanolime/lime (\%) } \\
\omega_{r}(\%)\end{array}$} & \multicolumn{6}{|c|}{$\%$ increment } \\
\hline & \multicolumn{5}{|c|}{ Soil-nanolime mixtures } & \multirow{2}{*}{$\begin{array}{l}\text { Soil-lime mixtures } \\
5.0\end{array}$} \\
\hline & 0.2 & 0.3 & 0.5 & 0.8 & 1.0 & \\
\hline 12 & 386 & 441 & 459 & 258 & 224 & 322 \\
\hline 14 & 371 & 396 & 426 & 235 & 200 & 318 \\
\hline 16 & 334 & 359 & 372 & 267 & 157 & 304 \\
\hline 18 & 162 & 322 & 336 & 273 & 262 & 327 \\
\hline
\end{tabular}

TABLE 5: UCS $\left(\mathrm{kN} / \mathrm{m}^{2}\right)$ value from Kassim and Chem [10] study.

\begin{tabular}{|c|c|c|c|c|c|c|}
\hline \multirow{2}{*}{ Soil } & \multirow{2}{*}{$\omega_{r}(\%)$} & \multirow{2}{*}{ Pure soil } & \multicolumn{2}{|c|}{ Curing period } & \multicolumn{2}{|c|}{$\%$ increment } \\
\hline & & & 28 days & 56 days & 28 days & 56 days \\
\hline Tapah kaolin & \multirow{5}{*}{$\begin{array}{c}\text { Optimum water } \\
\text { content }\end{array}$} & 24.4 & 145 & 275 & 580 & 1100 \\
\hline Pelepas marine & & 24.5 & 120 & 150 & 480 & 600 \\
\hline Sg Buloh clay & & 35.5 & 80 & 80 & 228 & 228 \\
\hline Jerangau clay & & 150.1 & 255 & 405 & 170 & 270 \\
\hline Kulai clay & & 38.1 & 50 & 130 & 142 & 371 \\
\hline
\end{tabular}

to $5 \%$. When the content of nanoparticles used was large, nanoparticles were not uniformly dispersed. Therefore, a weak area in the form of voids was created, consequently the homogeneous hydrated microstructure cannot be formed, and finally the strength decreased. Reduction in compressive strength by adding $2 \%$ nanoparticles may be due to the excess silica leaching out.

The results of UCS can also be compared with the results of the study conducted by Kassim and Chem [10] in Table 5. In that study, residual acidic soils were collected from different locations in Malaysia. The obtained soils were treated by lime and cured for a different curing period. The results of Kassim and Chem [10] were for soils treated with optimum lime content and cured for a period of 28 and 56 days. Jerangau clay was mixed with $3.0 \%$ lime and comparison was made with $0.5 \%$ nanolime and $5 \%$ lime mixtures. All samples were compacted at optimum water contents. The UCS of pure soils (i.e., Jerangau clay and studied original soil) was almost identical.

After 28 days and 56 days relatively, soil-nanolime mixtures at $0.2 \%, 0.3 \%$, and $0.5 \%$ exhibit increment in the UCS value (Table 6). These values are higher than the increment by soil-lime mixture at $5 \%$. The UCS increment was at $290 \%$ for soil-5\% lime mixtures and $342 \%$ for soil- $0.5 \%$ nanolime mixtures after 28 days' curing period. For 56 days' curing period, the UCS increment was at $327 \%$ for 
TABLE 6: UCS $\left(\mathrm{kN} / \mathrm{m}^{2}\right)$ value from current study.

\begin{tabular}{|c|c|c|c|c|c|c|c|c|c|c|}
\hline \multicolumn{11}{|c|}{ Current study } \\
\hline \multirow{3}{*}{ Soil } & \multirow{3}{*}{$\omega_{r}(\%)$} & \multirow{3}{*}{ Pure soil } & \multicolumn{4}{|c|}{ Curing Period } & \multicolumn{4}{|c|}{$\%$ increment } \\
\hline & & & \multicolumn{2}{|c|}{28 days } & \multicolumn{2}{|c|}{56 days } & \multicolumn{2}{|c|}{28 days } & \multicolumn{2}{|c|}{56 days } \\
\hline & & & $0.5 \%$ nanolime & $5.0 \%$ lime & $0.5 \%$ nanolime & $5.0 \%$ lime & $0.5 \%$ nanolime & $5.0 \%$ lime & $0.5 \%$ nanolime & $5.0 \%$ lime \\
\hline \multirow{4}{*}{ UKM soil } & $12^{* *}$ & 138 & 453 & 385 & 634 & 445 & 328 & 279 & 459 & 322 \\
\hline & $14^{* *}$ & 157 & 530 & 455 & 669 & 500 & 338 & 290 & 426 & 318 \\
\hline & $16^{*}$ & 184 & 630 & 512 & 685 & 559 & 342 & 278 & 372 & 304 \\
\hline & $18^{* *}$ & 74 & 242 & 204 & 249 & 272 & 327 & 276 & 336 & 327 \\
\hline
\end{tabular}

* Optimum water content of untreated soil.

${ }^{* *}$ Remolded water content.

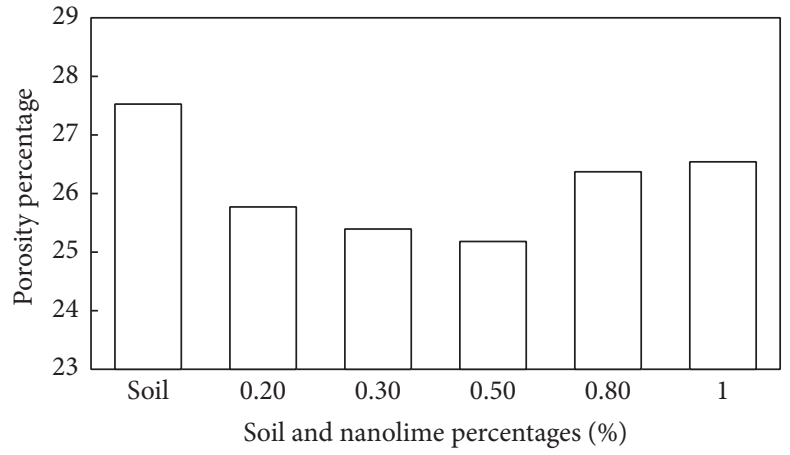

(a)

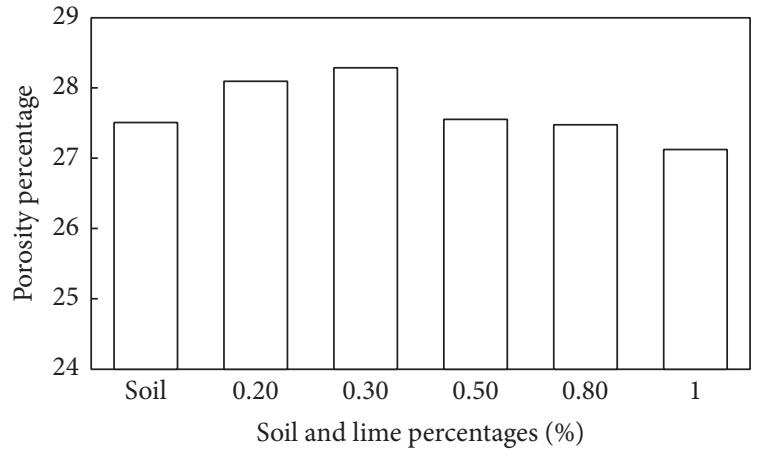

(b)

Figure 7: (a) Porosity percentage of soil and soil-nanolime mixtures. (b) Porosity percentage of soil and soil-lime mixtures.

TABLE 7: Average particle size and crystallite size of lime and nanolime.

\begin{tabular}{lcc}
\hline & $\begin{array}{c}\text { FESEM test: } \\
\text { average particle } \\
\text { size }\end{array}$ & $\begin{array}{c}\text { XRD test: } \\
\text { crystallite size }\end{array}$ \\
\hline Lime & $7.20 \mu \mathrm{m}$ & $75.44 \mathrm{~nm}$ \\
Nanolime & $21.03 \mathrm{~nm}$ & $19.36 \mathrm{~nm}$ \\
\hline
\end{tabular}

soil-5\% lime mixtures and $459 \%$ for soil- $0.5 \%$ nanolime mixtures.

5.2. Improvement Mechanism Investigation. The porosity of original soil which is $28 \%$ has been reduced with the addition of nanolime which could be seen in the formation of flocculation and agglomeration of the soil particles in the SEM images below. Lime considerably reduced the porosity at $0.8 \%$ and $1 \%$ of lime addition. Figures $7(\mathrm{a})$ and $7(\mathrm{~b})$ show the porosity percentages of soil and soil treated with additives: lime and nanolime.

In addition, the lime could fill only the micropores while nanolime could fill the micro- and nanopores. Table 7 shows the average particle size and crystallite size of lime and nanolime which was obtained from FESEM and XRD tests, respectively. The average particle size of lime was $7.20 \mu \mathrm{m}$ while nanolime was much smaller at $21.03 \mathrm{~nm}$ as studied. Through XRD tests, data were calculated using Scherer's formula to find the crystallite size of lime which was $75.44 \mathrm{~nm}$

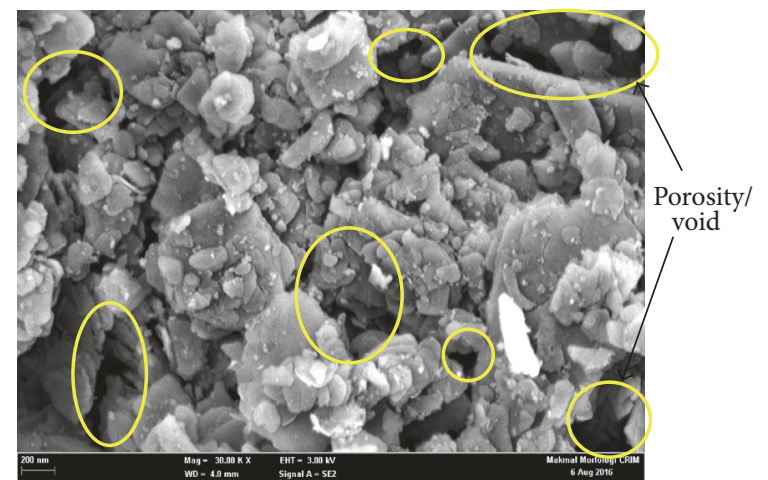

FIGURE 8: FESEM micrograph of original soil: $\mathrm{Mag}=30.00 \mathrm{KX}$.

and that of nanolime was $19.36 \mathrm{~nm}$. This also proved that the nanolime grains were much smaller compared to lime grains. This further supports the materials in nanodimensions which are very small particles with respect to the massive materials. Nanoparticles create positive changes in physical properties because of the increase in ratio of surface area and changes in volume. Due to the large surface area, nanoparticles become more reactive and suitable in improving the properties of clayey soil. This leads to an increase in strength of the soil.

5.3. FESEM Analysis. The FESEM images of original soil were presented in Figure 8 . The voids are seen clearly between the soil particles. Figures 9 and 10 show the micrograph 


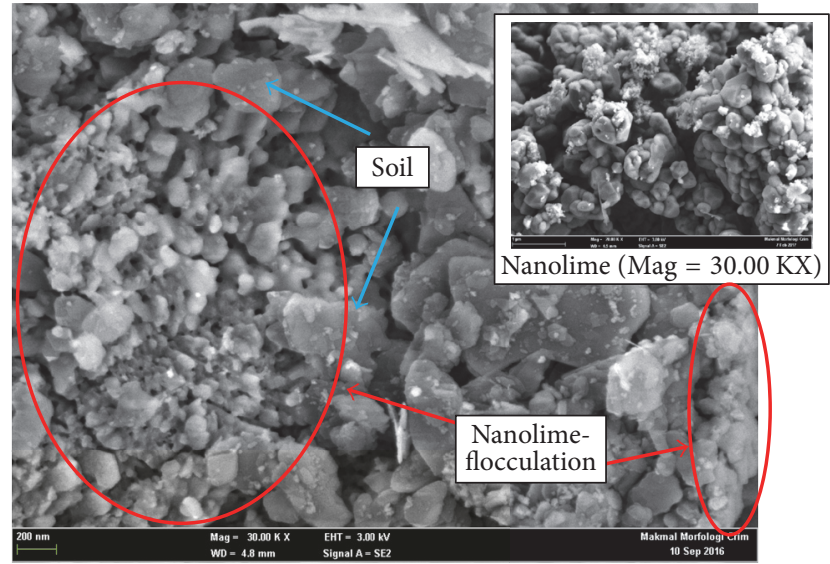

FiguRE 9: FESEM micrograph of soil- $0.5 \%$ nanolime: Mag = $30.00 \mathrm{KX}$.

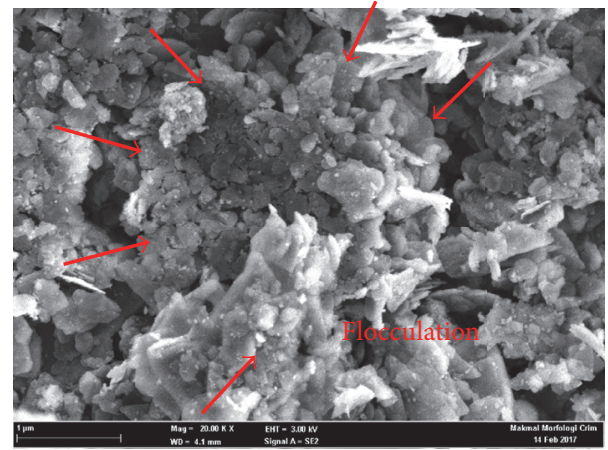

FIGURE 10: FESEM micrograph of soil-0.5\% nanolime: Mag = $20.00 \mathrm{KX}$.

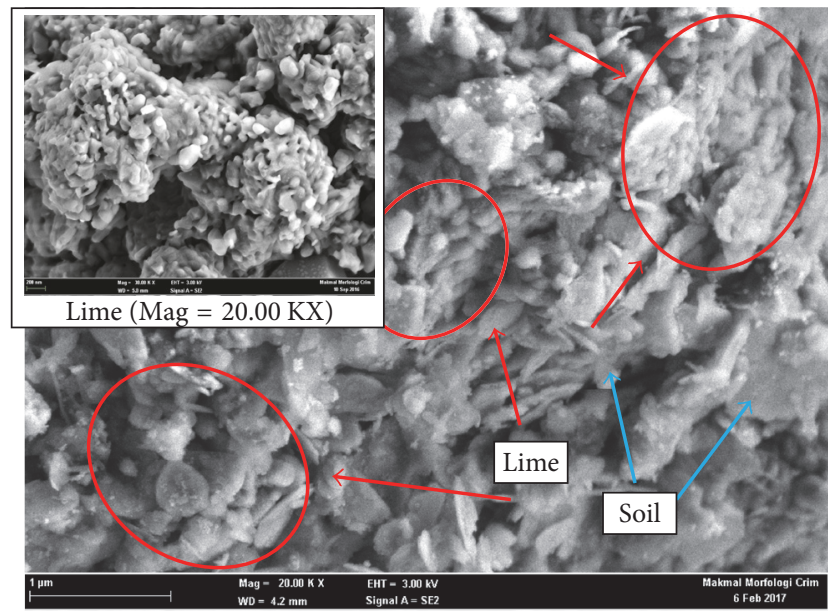

FIGURE 11: FESEM micrograph of soil-1\% lime: $\mathrm{Mag}=20.00 \mathrm{KX}$.

of soil mixed with $0.5 \%$ nanolime where it looks as a selfassembly or flocculation of gel-like particles, while soil mixed with 1\% lime shown in Figures 11 and 12 looks like soft and aggregated particles in chain-like shape. It can be seen that the nanolime particles agglomerated more than that of lime. This is possibly because of van der Waal forces developed

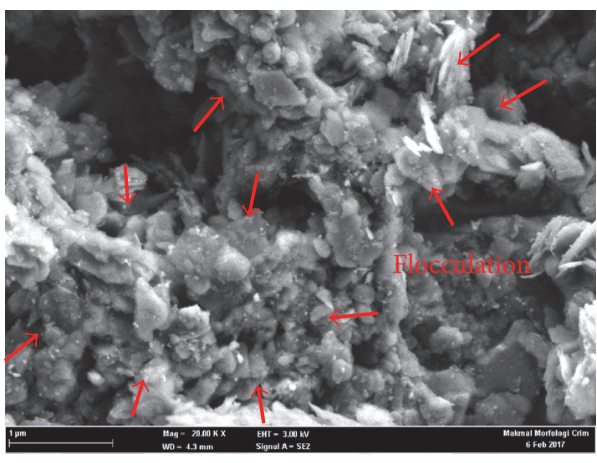

Figure 12: FESEM micrograph of soil-5\% lime: Mag = 20.00 KX.

between the nanoparticles. This morphology can be observed more clearly in Figure 11 and Figure 12 where the particles of soil-lime seemed to be discrete small particles with voids in contrast to soil-nanolime particles which appeared to be fine particles agglomerated in ball-like structure.

\section{Conclusion}

Nanolime shows superiority in soil improvement compared with lime even at the dosage of $0.5 \%$. Due to higher ability of nanolime to flocculate and agglomerate, the UCS of treated soil increased significantly over time with increasing percentage of nanolime from $0.2 \%$ until $0.5 \%$. The strength gain is inversely proportional to the remolded moisture content and curing period.

\section{Conflicts of Interest}

The authors declare that they have no conflicts of interest.

\section{Acknowledgments}

The authors would like to acknowledge Ministry of Higher Education (MOHE), Malaysia, UKM Geotechnical Laboratory, Pusat Pengurusan Penyelidikan dan Instrumentasi (CRIM), and staffs for their full support and guidance in doing this paper.

\section{References}

[1] S. Kazemian and B. B. K. Huat, "Assessment of stabilization methods for soft soils by admixtures," in Proceedings of the International Conference on Science and Social Research (CSSR '10), pp. 118-121, Kuala Lumpur, Malaysia, December 2010.

[2] C. McDowell, "Stabilization of soils with lime, lime-fly ash and other lime reactive materials," High Research Board Bulletin, vol. 231, pp. 60-66, 1959.

[3] National Lime Association, Lime-Treated Soil Construction Manual: Lime Stabilization and Lime Modification, 2004.

[4] G. H. Hilt and D. Davidson, "Lime fixation in clayey soils," Highway Research Board Bulletin, vol. 262, 1960.

[5] M. R. Taha and O. M. E. Taha, "Influence of nano-material on the expansive and shrinkage soil behavior," Journal of Nanoparticle Research, vol. 14, no. 10, article 1190, 13 pages, 2012. 
[6] P. Holister, J. W. Weener, C. Román, and T. Harper, "Nanoparticles," Technology White Papers 3, 2003.

[7] M. R. Taha, "Geotechnical properties of soil-ball milled soil mixtures," in Nanotechnology in Construction 3: Proceedings of the NICOM3, pp. 377-382, Springer, Berlin, Germany, 2009.

[8] F. Uddin, "Clays, nanoclays, and montmorillonite minerals," Metallurgical and Materials Transactions A: Physical Metallurgy and Materials Science, vol. 39, no. 12, pp. 2804-2814, 2008.

[9] V. Daniele, G. Taglieri, and R. Quaresima, “The nanolimes in Cultural Heritage conservation: characterisation and analysis of the carbonatation process," Journal of Cultural Heritage, vol. 9, no. 3, pp. 294-301, 2008.

[10] K. A. Kassim and K. K. Chem, "Lime stabilized Malaysian cohesive soils," Jurnal Kejuruteraan Awam, vol. 16, no. 1, pp. 13-23, 2004.

[11] J. R. Jones, D. J. Parker, and J. Bridgwater, "Axial mixing in a ploughshare mixer," Powder Technology, vol. 178, no. 2, pp. 7386, 2007.

[12] H. Willie and W. Norman, Methods of Soil Analysis: Part 5. Mineralogical Methods, Soil Science Society of America, 2007.

[13] A. W. Hull, "A new method of chemical analysis," Journal of the American Chemical Society, vol. 41, no. 8, pp. 1168-1175, 1919.

[14] M. Arabani, A. K. Haghi, A. Mohammadzade Sani, and N. Kamboozia, "Use of nanoclay for improvement of the microstructure and mechanical properties of soil stabilized by cement," in Proceedings of the 4th International Conference on Nanostructures, Kish Island, Iran, March 2012. 

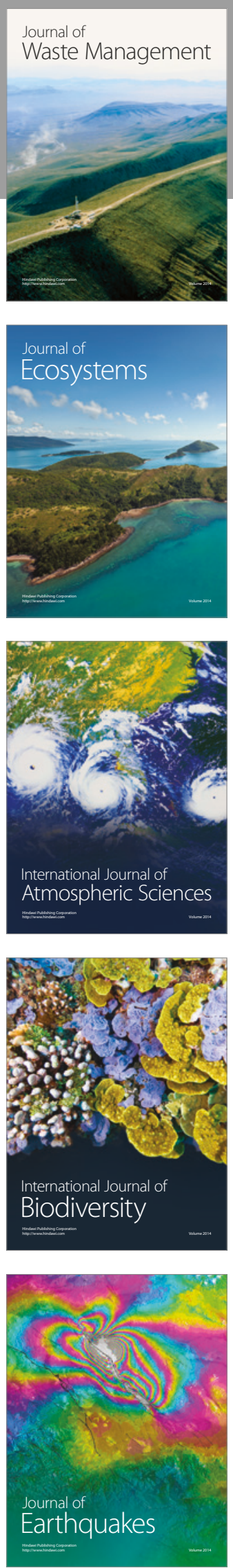
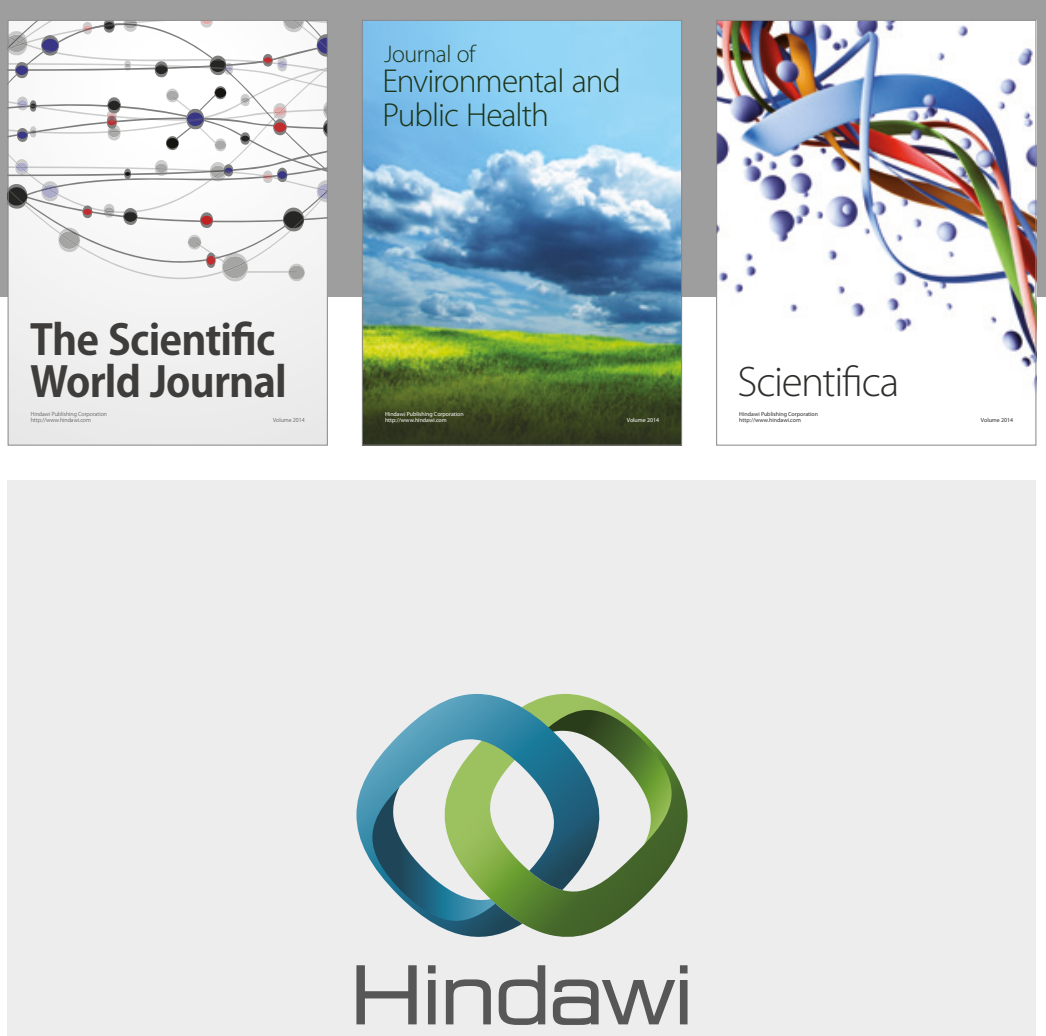

Submit your manuscripts at

https://www.hindawi.com
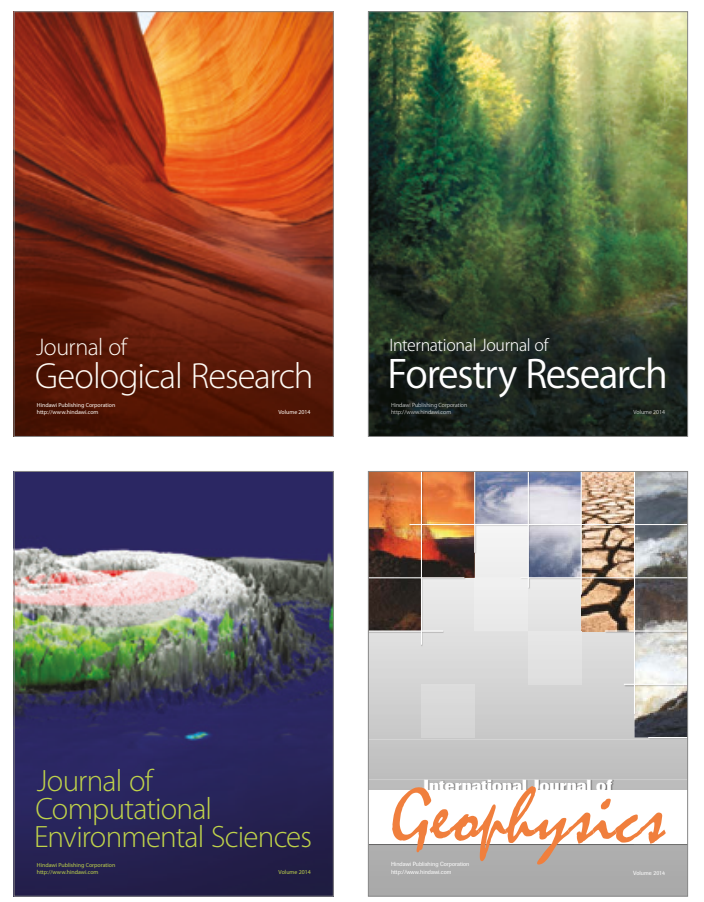
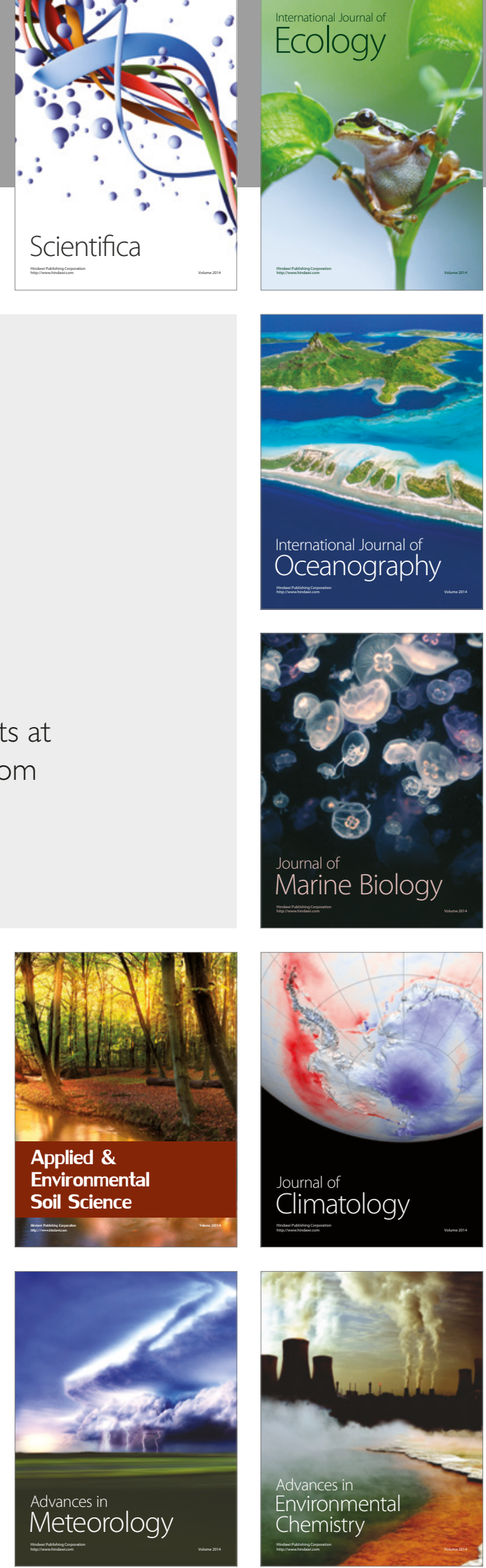